\title{
PENGARUH KUALIAS PRODUK, DISPLAY LAYOUT, DAN VARIASI PRODUK TERHADAP KEPUASAN KONSUMEN
}

\author{
Meilaty Finthariasari $^{1)}$; Sri Ekowati ${ }^{2)}$; Roy Krisna ${ }^{3)}$ \\ 1) Department of Management, Faculty of Economic and Business, \\ Universitas Muhammadiyah Bengkulu \\ Email: ${ }^{1)}$ mheyfinta@umb.ac.id
}

\section{How to Cite :}

Finthariasari, M. (2020). PENGARUH KUALITAS PROUK, DISPLAY LAYOUT DAN VARIASI PRODUK TERHADAP KEPUASAN KONSUMEN. EKOMBIS REVIEW: Jurnal IImiah Ekonomi Dan Bisnis, 8(2). DOI: https://doi.org/10.37676/ekombis.v8i2

\section{ARTICLE HISTORY}

Received [27 06 2020]

Revised [13 07 2020]

Accepted [28 07 2020]

\section{KEYWORDS}

Product Quality, Display

Layout, Product

Variations, Consumer Satisfaction

This is an open access article under the $C C-B Y-S A$ license

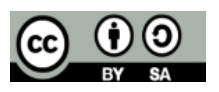

\section{ABSTRAK}

Penelitian ini bertujuan untuk mengetahui pengaruh kualias produk, display layout, dan variasi produk terhadap kepuasan konsumen toko kue Sarah Cake Kota Bengkulu. Penelitian ini merupakan penelitian kuantitatif dengan sampel berjumlah 190 orang responden, sampel ditarik berdasarkan rumus Hair et al. Teknik pengumpulan data dengan menggunakan observasi dan kuesioner. Data yang terkumpul kemudian diolah dengan alat bantu olah data SPSS 21 dan dianalisi menggunakan teknik analisis uji asumsi klasik, regresi linier berganda, Koefisien Determinasi (R2) dan uji hipotesis. Hasil penelitian ini dapat dilihat dari uji regresi linier berganda dengan yaitu $Y=$ $3.213+0.125(X 1)+0.177(X 2)+0.092(X 3)$. Dari hasil uji hipotesis secara parsial (uji T) bahwa masing-masing variable independen (kualitas produk, display layout, dan variasi produk) memiliki pengaruh positif signifikan terhadap variable dependen (kepuasan konsumen). Adupan besarnya pengaruh masing-masing variable independen terhadap variable dependen (kepuasan konsumen) adalah kualitas produk sebesar $26.25 \%$, display layout sebesar $62.10 \%$, dan variasi produk sebesar $25.13 \%$. Untuk hasil secara simultan (uji F) variable independen (kualitas produk, display layout, dan variasi produk) juga memiliki pengaruh positif signifikan terhadap variable dependen (kepuasan konsumen), yaitu sebesar $60.10 \%$.

\section{ABSTRACT}

This study aims at finding out the effect of product quality, display layout, and product variations on consumer satisfaction at the Sarah Cake Shop Bengkulu City. This study applied a quantitative study with a sample of 190 respondents. Samples drawn were based on the formula of Hair et al. The study employed observation and questionnaires 
when collecting data. The collected data were then processed with SPSS 21, and then analyzed using classic assumption test analysis techniques, multiple linear regression, Coefficient of Determination (R2), and hypothesis testing. The results of this study can be noticed from the multiple linear regression test with $Y=3.213+0.125(X 1)+0.177(X 2)+0.092(X 3)$. From the partial hypothesis test results ( $T$ test) revealed that each independent variable (product quality, display layout, and product variations) has a significant positive effect on the dependent variable (customer satisfaction). As for the great effect of each independent variable on the dependent variable (customer satisfaction) is product quality at $26.25 \%$, display layout at $62.10 \%$, and product variations at $25.13 \%$. For simultaneous results ( $F$ test) the independent variable (product quality, display layout, and product variations) also has a notable positive effect on the dependent variable (customer satisfaction), which is similar to $60.10 \%$.

\section{PENDAHULUAN}

Menurut Kepala Dinas Dukcapil Provinsi Bengkulu, M Ikhwan, Provinsi Bengkulu sendiri mengalami pertambahan penduduk sebanyak 2000 orang dari tahun 2018 kepertengahan semester tahun 2019 ini. Dengan semakin banyaknya pertambahan penduduk di Provinsi Bengkulu sehingga dengan demikian tingkat konsumsi masyarakat akan makanan juga akan meningkat. Hal ini dapat menjadi peluang bisnis kuliner yang menjanjikan bagi para pebisnis. Bisnis kuliner baik tradisional, maupun modern yang sedang berkembang pesat saat ini dan memiliki pangsa pasar yang menjanjikan seiring dengan pertambahan jumlah penduduk,

Berdasarkan hasil pengamatan peneliti selama 2 hari dari tanggal 20-21 November 2019 terhadap 20 pelanggan toko kue di Kota Bengkulu, 13 orang konsumen sering berpindah-pindah dalam berbelanja kue. Hal ini mengindikasikan bahwa konsumen tidak loyal pada satu toko. Salah satu faktor pelanggan tidak loyal adalah karena faktor ketidakpuasan mereka. Apabila ada toko kue yang baru dibuka, maka mereka akan beralih ketoko yang baru ini. Secara harfiah, hal ini merupakan hal yang wajar, karena kemungkinan pelanggan ingin merasakan hal baru misal dari sisi rasa dan pengalaman baru mencicipi menu yang ditawarkan dari toko yang baru ini.

Sementara, hasil wawancara awal yang peneliti lakukan selama 3 hari berikutnya secara berturut-turut dari tanggal 23-25 November 2019 pada 20 orang konsumen lainnya, menyatakan bahwa faktor yang berpengaruh terhadap kepuasan mereka adalah sebagai berikut:

Tabel 1 Hasil Survei Awal Pelanggan

\begin{tabular}{|l|l|c|c|}
\hline No & Variabel & Jumlah Pelanggan & Presentasi (\%) \\
\hline 1 & Kualitas Produk & 8 Orang & 40 \\
\hline 2 & Variasi Produk & 7 Orang & 35 \\
\hline 3 & Display layout & 5 Orang & 25 \\
\hline
\end{tabular}

150 | Meilaty Finthariasari ; Sri Ekowati ; Roy Krisna; Pengaruh Kualitas Prouk, Display Layout Dan Variasi Produk Terhadap Kepuasan Konsumen 


\begin{tabular}{|c|c|c|} 
Total Pelanggan & 20 Orang & 100 \\
\hline
\end{tabular}

Sumber: survei awal, 2019.

Hasil wawancara awal yang peneliti lakukan tersebut, diperoleh persepsi konsumen bahwa kepuasan mereka sebagai konsumen sangat dipengaruhi oleh faktor kualitas produk dan variasi produk yang dijual. Sementara jika peneliti amati pada beberapa toko kue yang ada di Kota Bengkulu seperti R\&R cake, Aroma Cake, dan Surya Bakery kualitas produk mereka baik dan bervariasi namun sepi pembeli. Kondisi yang hampir sama pada toko Sarah Cake dimana saat ini juga sudah mulai berkurang pembelinya dibandingkan dengan tahun lalu pada saat Toko ini baru buka. Menurut karyawan toko hal ini mungkin dapat disebabkan karena saat ini telah banyak took kue yang bermunculan yang menjual kue yang sejenis seperti yang dijual oleh took Sarah Cake ini. Adapun informasi omset toko Sarah Cake disajikan dalam Tabel berikut ini:

Tabel 2 Omset Toko Sarah Cake 6 Bulan Terakhir

\begin{tabular}{|c|l|}
\hline Bulan (2019) & Omset \\
\hline November & $59,789,000$ \\
\hline Oktober & $59,010,000$ \\
\hline September & $61,566,000$ \\
\hline Agustus & $58,478,000$ \\
\hline Juli & $65,735,000$ \\
\hline Juni & $68,335,000$ \\
\hline Total Omset 6 Bulan & $372,913,000$ \\
\hline
\end{tabular}

Sumber: Toko Sarah Cake Bengkulu

Berdasarkan data Tabel 2 di atas, hasil survey awal kepada beberapa konsumen yang menjadi narasumber, maupun pengamatan peneliti yang telah dijabarkan di atas, maka peneliti sangat tertarik untuk melakukan penelitian saat ini dengan judul "Analisis Pengaruh Kualias Produk, Display Layout, Dan Variasi Produk Terhadap Kepuasan Pelanggan (Studi Terhadap Pelanggan Toko Kue Sarah Cake di Kota Bengkulu)".

\section{LANDASAN TEORI}

\section{Kepuasan Konsumen}

Kotler dan Keller (2007) menyatakan kepuasan konsumen adalah perasaan senang atau kecewa seseorang yang muncul setelah membandingkan kinerja (hasil) produk yang dipikirkan terhadap kinerja yang diharapkan. Keputusan konsumen untuk membeli suatu produk ditempat tertentu akan sangat dipengaruhi oleh tingkat kepuasaan yang akan diprolehnya. Menurut Hiam Dan schewe dalam Finthariasari (2017) tahap-tahap pengambilan keputusan pembelian konsumen meliputi: pengenalan masalah, pencarian informasi intern dan esktern, keputusan setelah konsumen memperoleh informasi baik intren maupun estern, dan evaluasi pasca pembelian. Adapun indikator dalam mengukur kepuasan pelanggan menurut Danes et al (2012) diantaranya adalah:

1. Pelanggan merasa senang belanja di toko tertentu. 
2. Toko ini memenuhi harapan pelanggan.

3. Pelanggan memilih toko ini kembali di masa yang akan datang.

Beberapa manfaat jika perusahaan dapat memenuhi kebutuhan pelanggan sehingga pelanggan menjadi puas, diantaranya (Tjiptono, 2008):

1. Terbentuk hubungan yang baik dan jangka panjang antara pelanggan dan perusahaan.

2. Terbuka peluang bisnis baru melalui cross selling dan up selling.

3. Terciptanya loyalitas pelanggan.

4. Reputasi perushaan akan semakin baik dimata pelanggan.

5. Meningkatkan laba penjualan.

\section{Kualitas Produk}

Shum (2010) mengutip terdapat empat pendekatan yang digunakan dalam mendefinisikan kualitas pada disiplin ilmu yang berbeda, yaitu; pendekatan berbasis produk, arti kualitas dimaknai dengan ukuran, seperti fitur (features), fungsi (functions), dan kinerja (performance). Kambhu (1982) mendefiniskan kualitas sebagai deskripsi atas teknik (technical) dan pisik (physical); pendekatan berbasis pabrikan mendefinisikan kualitas sebagai kesesuaian standar dan spesifikasi (specification). Crosby (1979) mendefinisikan kualitas sebagai kesesuaian persyaratan (requirements). Juran, Gryna dan Bingham, (1974) mendefinisikan kualitas sebagai fitness for use; untuk pendekatan berbasis pengguna, Kotler (2001) mendefinisikan kualitas sebagai kemampuan dari fitur (ability of features) dan karakteristik produk (characteristics of a product); pendekatan berbasis nilai, kualitas didefinisikan dalam bentuk biaya (cost) dan harga (price)".

Menurut Garvin (1987), kualitas produk memiliki delapan dimensi yaitu kinerja (performance), fitur (features), keandalan (reliability), kesesuaian (conformance), daya tahan (durability), kemampuan layanan (service ability), estetika (aesthetics), dan kualitas yang dipersepsikan (perceived quality). Menurut Tjiptono et al (2008), indikator kualitas produk diantaranya:

1. Menu yang beraneka ragam,

2. Rasa yang enak,

3. Rasa stabil, dan

4. Higienis.

\section{Display Layout}

Display layout merupakan tata letak produk, kasir dan arus lalu lalang konsumen di dalam toko. Pemilik dan pengelola harus merancang tata letak produk yang menarik dan mudah dijangkau oleh konsumen. Display layout produk juga harus memudahkan konsumen berjalan dan berlalu lalang, sehingga ia bisa mencari dan memperoleh barang yang dibutuhkannya dengan mudah dan cepat. Prinsipnya, tata letak semua elemen di dalam toko harus menciptakan suasana yang menyenangkan bagi semua pihak:konsumen, petugas, dan produsen (Yuliana, 2015). Menurut Yuliana (2015), indicator display layout diantaranya adalah:

1. Tata letak produk

2. Penataan produk terlihat menarik

3. Penataan produk terlihat rapi

4. Penataan produk memudahkan pelanggan dalam mencari barang yang diinginkan

5. Tata Letak Kasir

6. Penempatan meja kasir strategis dan tepat

152 | Meilaty Finthariasari ; Sri Ekowati ; Roy Krisna; Pengaruh Kualitas Prouk, Display Layout Dan Variasi Produk Terhadap Kepuasan Konsumen 
7. Penempatan meja kasir memudahkan saya dalam transaksi pembayaran

8. Arus Lalu Lalang Konsumen

9. Layout toko tidak berliku-liku sehingga memudahkan pelanggan dalam membawa barang.

10. Lebar jalan di dalam toko memudahkan pelanggan untuk berlalu lalang.

\section{Variasi Produk}

Menurut Kotler dan Keller (2007), produk adalah segala sesuatu yang dapat ditawarkan ke pasar untuk memuaskan keinginan dan kebutuhan. Produk-produk yang dipasarkan meliputi barang fisik, jasa, pengalaman, acara-acara, orang, tempat, properti, organisasi, dan gagasan. Setiap produk secara hirarki berhubungan dengan produk tertentu lainnya (Kotler, 2003). Variasi produk merupakan daya tarik bagi konsumen terutama dapat memberikan alternative pilihan yang lebih bervariasi. Alternative pilihan yang lebih bervariasi bagi konsumen dapat mendorong kepuasan konsumen (Botti \& lyengar 2006). Menutut Engel et al dalam Setianingsih (2016), indikator variasi produk terdiri dari:

1. Kelengkapan produk

2. Merek produk

3. Variasi ukuran produk

4. Kualitas produk

Pajak menurut Undang - Undang Nomor 16 Tahun 2009, Pasal 1 ayat (1) Pajak adalah kontribusi wajib kepada Negara yang terutang oleh orang pribadi ataubadan yang bersifat memaksa berdasarkan Undang-Undang dengan tidak mendapatkan imbalan secara langsung dan digunakan untuk keperluan Negara bagisebesar-besarnya kemakmuran rakyat.

\section{Metode Analisis}

\section{METODE PENELITIAN}

Jenis penelitian yang digunakan deskriptif kuantitatif. Populasi dalam penelitian ini adalah konsumen pada Toko Sarah Cake Kota Bengkulu. Jumlah sample ditentukan dengan menggunakan rumus Hair et al (2006), dimana sampel dapat dihitung berdasarkan jumlah indicator/item pernyataan dikali 5-10. Adapun jumlah sampel dalam penelitian ini berjumlah 190 orang. Tahap uji instrument akan dilakukan untuk menganalisis validitas dan reliabilitas kuesioner yang akan digunakan dalam penelitian. Data penelitian dikumpulkan dengan teknik observasi dan menyebarkan kuesioner. Selanjutnya dilakukan uji asumsi klasik yang berguna untuk menganalisis tingkat normalitas data sebelum diolah dalam tahap selanjutnya. Tahap berikutnya adalah menganalisis data dengan menggunakan teknik analisis regresi linier berganda dan uji hipotesis melalui uji T dan uji F.

\section{Pembahasan}

\section{HASIL DAN PEMBAHASAN}

\section{Analisis Regresi Linier Berganda}

Tabel 3. Persamaan Regresi

Coefficientsa

\begin{tabular}{|c|c|l|l|l|l|}
\hline \multirow{2}{*}{ Model } & \multicolumn{2}{|l|}{$\begin{array}{l}\text { Unstandardized } \\
\text { Coefficients }\end{array}$} & $\begin{array}{l}\text { Standardized } \\
\text { Coefficients }\end{array}$ \\
\cline { 2 - 5 } & $\mathrm{B}$ & Std. Error & Beta & \multirow{2}{*}{ Sig. } \\
\hline
\end{tabular}




\begin{tabular}{|c|l|l|l|l|l|} 
(Constant) & 3.213 & .672 & & 4.781 & .000 \\
$\mathrm{X} 1$ & .125 & .048 & .181 & 2.625 & .009 \\
$\mathrm{X} 2$ & .177 & .028 & .462 & 6.210 & .000 \\
$\mathrm{X} 3$ & .092 & .036 & .161 & 2.513 & .013 \\
\hline
\end{tabular}

Sumber: Olah Data, 2020

Berdasarkan Tabel 3, didapat persamaan regresi sebagai berikut:

$$
\mathbf{Y}=3.213+0.125(\mathrm{X} 1)+0.177(\mathrm{X} 2)+0.092(\mathrm{X} 3)
$$

Keterangan:

Y : Kepuasan konsumen

$\mathrm{X} 1 \quad$ : Kualitas Produk

X2 : Display Layout

X3 : Variasi Produk

Untuk menganalisis koefisien regresi masing-masing variabel dalam penelitian ini dapat dijelaskan sebagai berikut :

1. Nilai a (constanta) sebesar 3.213 mempunyai arti bahwa apabila variable kualitas produk (X1), display layout (X2), dan variasi produk (X3) sama dengan nol maka variable kepuasan konsumen akan tetap sebesar 3.213, hal ini hanya berlaku saat dilakukan penelitian.

2. Koefisien regresi variabel kualitas produk (X1) sebesar 0.125 mempunyai makna bahwa apabila kualitas produk (X1) ditingkatkan satu satuan, maka akan meningkatkan variable kepuasan konsumen $(Y)$ toko Sarah cake sebesar 0.125 dengan asumsi variabel display layout (X2) dan variasi produk (X3) dianggap tetap.

3. Koefisien regresi variabel display layout $(X 2)$ sebesar 0.177 mempunyai makna bahwa apabila display layout (X2) ditingkatkan satu satuan, maka akan meningkatkan variable kepuasan konsumen $(Y)$ toko Sarah cake sebesar 0.177 dengan asumsi variabel kualitas produk (X1) dan variasi produk (X3) dianggap tetap.

4. Koefisien regresi variabel variasi produk (X3) sebesar 0.092 mempunyai makna bahwa apabila variasi produk (X3) ditingkatkan satu satuan, maka akan meningkatkan variable kepuasan konsumen $(Y)$ toko Sarah cake sebesar 0.092 dengan asumsi variabel kualitas produk (X1) dan display layout (X2) dianggap tetap.

\section{Uji Koefisien Determinasi (R2)}

Tabel 4. Uji Koefisien Determinasi (R2)

Model Summaryb

\begin{tabular}{|c|c|c|c|c|c|}
\hline Model & $R$ & $\begin{array}{l}\text { R } \\
\text { Square }\end{array}$ & $\begin{array}{l}\text { Adjusted } \quad R \\
\text { Square }\end{array}$ & $\begin{array}{l}\text { Std. Error of } \\
\text { the Estimate }\end{array}$ & Durbin-Watson \\
\hline 1 & ,702a & .492 & .484 & 1.114 & 1.579 \\
\hline
\end{tabular}

154 | Meilaty Finthariasari ; Sri Ekowati ; Roy Krisna; Pengaruh Kualitas Prouk, Display Layout Dan Variasi Produk Terhadap Kepuasan Konsumen 
a. Predictors: (Constant), X3, X2, X1

b. Dependent Variable: $Y$

Sumber: Olah Data, 2020

Berdasarkan hasil olah data di atas didapat koefisien korelasi (R) sebesar 0.702 , ini menandakan bahwa variable kualitas produk (X1), display layout (X2), dan variasi produk (X3) terhadap variable kepuasan konsumen adalah kuat dan signifikan. Dan koefisien determinasi sederhana ( $R$ square) $R 2=0.492$ dimana nilai koefisien determinasi tersebut mempunyai arti bahwa secara bersama-sama variable kualitas produk (X1), display layout (X2), dan variasi produk (X3) memberikan sumbangan dalam mempengaruhi kepuasan konsumen pada toko Sarah cake sebesar $49.2 \%$ sedangkan sisanya $50.8 \%$ dipengaruhi oleh variabel lain diluar variabel penelitian.

\section{Uji Hipotesis}

Table 5. Hasil Uji T (Parsial)

\begin{tabular}{|c|c|c|c|c|c|c|c|}
\hline \multirow[b]{2}{*}{ Model } & \multicolumn{2}{|c|}{$\begin{array}{l}\text { Unstandardized } \\
\text { Coefficients }\end{array}$} & \multirow{2}{*}{$\begin{array}{l}\text { Standardized } \\
\text { Coefficients } \\
\text { Beta }\end{array}$} & \multirow{2}{*}{ thitung } & \multirow{2}{*}{ Sig. } & \multirow[b]{2}{*}{ ttabel } & \multirow[t]{2}{*}{ Kriteria } \\
\hline & B & $\begin{array}{l}\text { Std. } \\
\text { Error }\end{array}$ & & & & & \\
\hline $\begin{array}{l}\text { (Cons } \\
\operatorname{tant)}\end{array}$ & 3.213 & .672 & & 4.781 & .000 & 1.960 & Sig. \\
\hline$X 1$ & .125 & .048 & .181 & 2.625 & .009 & 1.960 & Sig. \\
\hline$x 2$ & .177 & .028 & .462 & 6.210 & .000 & 1.960 & Sig. \\
\hline X3 & .092 & .036 & .161 & 2.513 & .013 & 1.960 & Sig. \\
\hline
\end{tabular}

Df $=190-4-1=185$

Sumber: Olah Data, 2020

Berdasarkan hasil uji t (secara parsial) yang ditunjukan pada Tabel 5 di atas dapat dianalisis sebagai berikut:

1. Pengaruh variable kualitas produk terhadap kepuasan konsumen

Tabel 5 menunjukkan hasil uji thitung $>$ ttabel variable kualitas produk terhadap kepuasan konsumen yaitu sebesar $2.625>1.960$. Hal ini berarti bahwa hipotesis pertama dalam penelitian ini diterima.

2. Pengaruh variable display layout terhadap kepuasan konsumen

Hasil uji thitung > ttabel variable display layout terhadap kepuasan konsumen yaitu sebesar $6.210>1.960$. Hal ini berarti bahwa hipotesis kedua dalam penelitian ini diterima.

3. Pengaruh variable variasi produk terhadap kepuasan konsumen

Sementara hasil uji thitung $>$ ttabel variable variasi produk terhadap kepuasan konsumen yaitu sebesar $2.513>1.960$. Hal ini berarti bahwa hipotesis ketiga dalam penelitian ini diterima.

\section{Uji F (Simultan)}

Table 6 Hasil Uji F (Simultan) ANOVAa 


\begin{tabular}{|c|c|c|c|c|c|}
\hline Model & $\begin{array}{l}\text { Sum of } \\
\text { Squares }\end{array}$ & $d f$ & $\begin{array}{l}\text { Mean } \\
\text { Square }\end{array}$ & $\mathrm{F}$ & Sig. \\
\hline 1 Regression & 223.763 & 3 & 74.588 & 60.107 &, $000 \mathrm{~b}$ \\
\hline Residual & 230.811 & 186 & 1.241 & & \\
\hline Total & 454.574 & 189 & & & \\
\hline
\end{tabular}
a. Dependent Variable: $Y$
b. Predictors: (Constant), X3, X2, X1

Sumber: Olah Data, 2020

Berdasarkan hasil perhitungan Tabel Anova yang disajikan dalam Tabel 6 di atas, diperoleh nilai Fhitung sebesar 60.107 dan sig 0,000. Ftabel pada taraf $\alpha=0.05$, df $1=$ (jumlah variabel independen $=3$ ) dan df2 $(n-k)=190-3=187$ ), maka nilai Ftabel $=3.89$. Hal ini berarti Fhitung $>$ Ftabel $(60.107>3.89)$ dan sig $<0.05(0.000$ $<0.05)$, hal ini menunjukkan bahwa Ho ditolak dan Ha diterima dengan demikian secara keseluruhan variabel kualitas produk, display layout, dan variasi produk mempunyai pengaruh yang positif dan signifikan terhadap terhadap kepuasan konsumen Toko Kue Sarah cake Bengkulu. Tingkat signifikan secara keseluruhan sebesar 0.000a ini menandakan terdapat hubungan yang signifikan dari uji keseluruhan variabel yang diteliti.

\section{Pengaruh Variabel Kualitas Produk Terhadap Kepuasan Konsumen}

Dari hasil analisis yang telah dipaparkan diatas, dapat peneliti simpulkan bahwa variable kualitas produk memiliki pengaruh yang positif signifikan terhadap kepuasan konsumen Toko Kue Sarah cake Bengkulu. Artinya bahwan hipotesis pertama yang diajukan dalam penelitian ini diterima.

\section{Pengaruh Variabel Display Layout Terhadap Kepuasan Pelanggan}

Hasil analisis yang telah dipaparkan diatas, dapat disimpulkan bahwa variable display layout memiliki pengaruh yang positif signifikan terhadap kepuasan konsumen Toko Kue Sarah cake Bengkulu. Artinya bahwan hipotesis kedua yang diajukan dalam penelitian ini diterima.

\section{Pengaruh Variabel Variasi Produk Terhadap Kepuasan Pelanggan}

Kemudian untuk membahas hasil analisis yang telah dipaparkan diatas, dapat peneliti simpulkan bahwa variable variasi produk memiliki pengaruh yang positif signifikan terhadap kepuasan konsumen Toko Kue Sarah cake Bengkulu. Artinya bahwan hipotesis ketiga yang diajukan dalam penelitian ini diterima.

\section{Pengaruh Variabel Kualitas Produk, Display Layout, dan Variasi Produk Terhadap Kepuasan Pelanggan}

Jika dilihat dari hasil analisis perhitungan table uji T yang telah dipaparkan di atas, serta pembahasan hasil penelitian mengenai pengaruh antara variable independen $(X 1, X 2$, dan $X 3)$ terhadap variable dependen $(Y)$ secara parsial. Bahwa masing-masing variable independen $(X 1, X 2$, dan $X 3)$ memiliki pengaruh positif yang signifikan terhadap variable dependen (Y). Kemudian untuk hasil analisis uji $F$ 
menyatakan bahwa secara simultan pun menunjukan bahwa variable independen $(X 1, X 2$, dan $X 3)$ memiliki pengaruh positif yang signifikan terhadap variable dependen (Y). Hubungan positif signifikan secara simultan antara 2 variabel independen dan dependen ini terjadi karena adanya hubungan positif yang disumbangkan dari masing-masing variabel independen terhadap variabel dependen.

\section{Kesimpulan}

\section{KESIMPULAN DAN SARAN}

Berdasarkan hasil penelitian yang dilakukan, maka dapat ditarik kesimpulan sebagai berikut : Terdapat pengaruh positif signifikan antara variable kualitas produk terhadap variable kepuasan konsumen pada Toko Kue Sarah Cake di Kota Bengkulu. Terdapat pengaruh positif signifikan antara variable display layout terhadap variable kepuasan konsumen pada Toko Kue Sarah Cake di Kota Bengkulu. Terdapat pengaruh positif signifikan antara variable variasi produk terhadap variable kepuasan konsumen pada Toko Kue Sarah Cake di Kota Bengkulu.

\section{Saran}

Dalam penelitian ini dikatakan bahwa kepuasan konsumen adalah baik, namun hal ini terjadi karena variable yang diteliti dalam penelitian ini adalah variable kualitas produk, display layout, dan variasi produk, dimana tiga variable ini ditanggapi baik oleh para responden yang ada. Namun yang sangat perlu menjadi perhatian bagi Toko Kue Sarah Cake di Kota Bengkulu adalah berkaitan dengan factor-faktor lain yang dapat memicu terbentuknya kepuasan pelanggan yang pada akhirnya dapat mempengaruhi tingkat omset bulanan dan tahunan toko ini.

\section{DAFTAR PUSTAKA}

Anggraini., Handoko, T. Hani. (2016). Pengaruh Komitmen Organisasional terhadap Turnover Intention. Tesis. http://etd.repository.ugm.ac.id/penelitian/detail/98617 
Botti, S. \& lyengar, S.S. (2006). The Dark Side of Choice: When Choice Impairs Social Welfare. Journal of Public Policy \& Marketing, 25(1), pp.24-38.

Danesh, Seiedeh Nasrin., Nasab, Saeid Ahmadi., \& Ling, Kwek Choon. (2012). The Study of Customer Satisfaction, Customer Trust and Switching Barriers on Customer Retention in Malaysia Hypermarkets. International Journal of Business And Management, vol.7, no 7.

Finthariasari, Meilaty. (2017). Analisis Faktor Yang Mempengaruhi Perilaku Konsumen Terhadap Keputusan Memilih Tempat Wisata Di Provinsi Bengkulu (Studi pada pengunjung Taman Wisata Family Kab. Bengkulu Tengah). Media Ekonomi Dan Bisnis Fakultas Ekonomi Univ. Muhammadiyah Bengkulu, Vol 16.

Garvin, D.A. (1987). Competing on the Eight Dimensions of Quality, Harvard Business Review, November-December, 101-109.

Juran, Gryna dan Bingham. (1974). Quality Control Handbook.

Kotler, Philip. (2000). Marketing Management: Analysis, Planning, Implementation, and Control, Tenth Edition. Prentice Hall International, Inc., New Jersey.

Kotler, Philip. (2007). ManajemenPemasaran, edisi kedua belas, jilid 1 dan 2. Jakarta: PT. Index.

Mantauv, Citra Suci. 2014. Pengaruh Harga Dan Kergaman Produk Terhadap Kepuasan Konsumen (di PT. Prioritas Sinar Ampek).

Setianingsih, Nur Fajar. (2016). Pengaruh Persepsi Harga, Keragaman Produk, Dan Suasana Toko Terhadap Keputusan Pembelian (Studi Pada Konsumen Dunkin Donuts Ambarukmo Plaza Yogyakarta). Skripsi.

Shum, Y.Y. (2010). The Effect of Perceived Product Quality and Perceived Service Quality on Customer Satisfaction and Loyalty in Fast Fashion Relailers. Thesis. Hong Kong. The Hong Kong Polytechnic University.

Tjiptono, Fandy; Gregorius Chandra; Dadi Adriana. (2008). Pemasaran Strategik. Edisi 1. Yogyakarta : Andi.

Wilujeng, Sri., \& Mudzakkir, Mohammad Fakhruddin. (2015). Pengaruh Keragaman Produk Terhadap Kepuasan Pelanggan Pada Toko Modern Indomaret Kecamatan Sukun Kota Malang. Jurnal Modernisasi, Volume 11, Nomor 2.

Wulandari, Ida Ayu., dan Adnyani, I Gusti Ayu. (2016). Pengaruh Work Family Conflict Terhadap Turnover Intention Melalui Mediasi Kepuasan Kerja Pada Hotel Grand Inna Kuta. E-Jurnal Manajemen Unud, Vol. 5, No. 10. ISSN : 23028912.

Yuliana. (2015). Pengaruh variasi produk dan display layout terhadap Minat konsumen muslim di toko bandeng juwana elrina Semarang. Skripsi. http://eprints.walisongo.ac.id/4353/

158 | Meilaty Finthariasari ; Sri Ekowati ; Roy Krisna; Pengaruh Kualitas Prouk, Display Layout Dan Variasi Produk Terhadap Kepuasan Konsumen 